\title{
MOTIVATION DEPENDENCE OF BRAIN SELF-STIMULATION IN THE PIGEON
}

\author{
JUAN D DELIUS*, ALAN S WILLIAMS** and ROBERT J WOOTTON*** \\ Department of Psychologv, Durham Linuersitv (Great Britain)
}

\begin{abstract}
Delıus, J D , Willıams, A S and Wootton, R J, 1976 Motıvatıon dependence of brain self stimulation in the pigeon Behau Processes, 1 15-27

Several brain sites in the pigeon were identıfied as maintaınıng electrical brain selfstimulation Depending on the site, stimulus currents yıelding maxımal responding varied from 20 to $160 \mu \mathrm{A}$ A high proportion of the sites only yielded self-stimulation behaviour If the subjects were deprived of food, when the birds were at full weight there was only one site at which the stimulation continued to be rewarding Some, but weak, evidence of stımulus satiation was found Overt behaviour elicited by non-contingent stimulation did not correlate with the reinforcing or neutral nature of the sites tested While some positive sites were associated with structures known to be involved in the control of feeding, others were not The hy pothesis that stımulation at the hunger-dependent sites might have elicited temporary satiation signals is considered
\end{abstract}

\section{INTRODUCTION}

Since the phenomenon of self-stimulation was discovered in 1954 a vast amount of information has been amassed about it However, research has been virtually restricted to mammals, or more precisely to rats There is still very little known about its occurrence and properties in non-mammalian species Initially the research reported in this paper was conceived as an exploratory study on reinforcing electrical brain stimulation in burds and, accordingly, we have also included information that does not directly bear on the title-theme

In rats it is not necessary for a suitable motivating state to be induced for operant conditioning with a brain-stimulation reinforcement to proceed (Reynolds, 1958, Olds, 1958a) Conventional rewards on the other hand usually are not effective without such treatment This contrast has been the source of some theoretical imperspicuity and indeed, ingenuity (see Gallistel, 1973,

\footnotetext{
Present addresses

* Department of Psychology, Ruhr-Universitat, Bochum (Federal Republic of Germany)

** Department of Psychology, Bırkbeck College, London (Great Britain)

*** Department of Zoology, Unıversity College, Aberystwyth (Great Britain)
} 
Lenzer, 1972. Rolls, 1975) We present data suggestıng that, at least in the pigeon (Columba lic'a), the discrepancy might not be as general as is assumed In this species electıcal stimulation of many brain sites only supports instrumental performance if an adequate drive state has been previously instituted

\section{MFTHODS}

Sixteen adult pigeons of local homing stock and undetermined sex were anaesthetized with Equithesin (intiamuscular, $025 \mathrm{ml} / 100 \mathrm{~g}$ ), then implanted with up to 8 intra-cerebral electrodes terminating in miniature sockets cemented to the skull The uninsulated electiode tips had a surface of between 02 and $03 \mathrm{~mm}^{2}$ (Delıus, 1966) The implanting was done stereotactically according to the Karten and Hodos (1967) pigeon brain atlas using a modified StellarJohnson apparatus \& 5 -cm length of bare stainless steel wire placed under the scalp served as the neutral electrode One week after the operation the animals were deprived of food to $80^{\prime \prime} \mathrm{c}$ of their normal weight $(350-450 \mathrm{~g})$ and shaped to peck a key for access to food in a Skınner box A pigeon box with a food hopper that projected into the box was used for all experiments $50-\mathrm{Hz}$ sine currents of up to $200 \mu \mathrm{A} \mathrm{r} \mathrm{m} \mathrm{s}$ could be delivered with a constant current stımulator via counterbalanced hearing-ald cables to a miniature connector plug On occasions, ballrace swivel contacts were used to take up cable torsion The stımulus currents were monıtored (as a voltage drop across a series resistor) with an oscilloscope throughout the experiments The contingencies and the timing of the events in the Skinner box were programmed with conventional relay equipment The animals' responses were registered with a cumulative recorder and electromagnetic counters Further procedural detals will be given helow The stimulation sites are identified by a three-digit number, where the first two digits specify the subject and the third the electrode

\section{RESULTS}

\section{Identification of rewarding sites}

An experiment of a design similar to that used by Goodman and Brown (1966) was used to identıfy electrodes whose stimulation had reinforcing propertıes The rate of key-peckıng was measured whıle the birds were at $80 \%$ of their normal weight for each of the electrodes under three conditions (a) when each peck led to $4 \mathrm{~s}$ access to food (food reward condition), (b) when a peck yielded a $1 \mathrm{~s}$ (early experiments) or $04 \mathrm{~s}$ (later experıments) current train of $120 \mu \mathrm{A}$ (self-stimulation condition), and (c) when a peck had no sequel (extinction condition) Each condition was tested 6 times in randomized blocks consisting of three 10-min sessions Each block was separated by approximately 24 hours Of the 68 sites examined, 17 gave an average of at least 3 times more responses during the self-stimulation condition than during the extinction 
condition and were classified as rewarding In fact these sites could be recognized easily on the basis of the cumulative records While the response scores varied from block to block depending on the order of the conditions, the cumulative records of such sites regularly climbed with a steady, if sometımes shallow, slope during the self-stimulation condition In the extinction condition the records invariably showed the characteristic, progressively decreasing slope (Fig 1)

Two electrodes gave on average one third or fewer responses during the self-stimulation condition than during the extinction condition, and were tentatively classified as aversive The experiment however, was not favourable for the detection of aversive sites because the low response rate during extinction hardly allowed the recognition of a further response depression durnng self-stımulation (see also Macphall, 1967, Goodman and Brown, 1966।

\section{Stımulation current}

For 14 of the rewarding electrodes we determined the current level that yielded maximum response rates The plgeons continued at $80 \%$ of their normal weight but received no food reinforcement Five different current

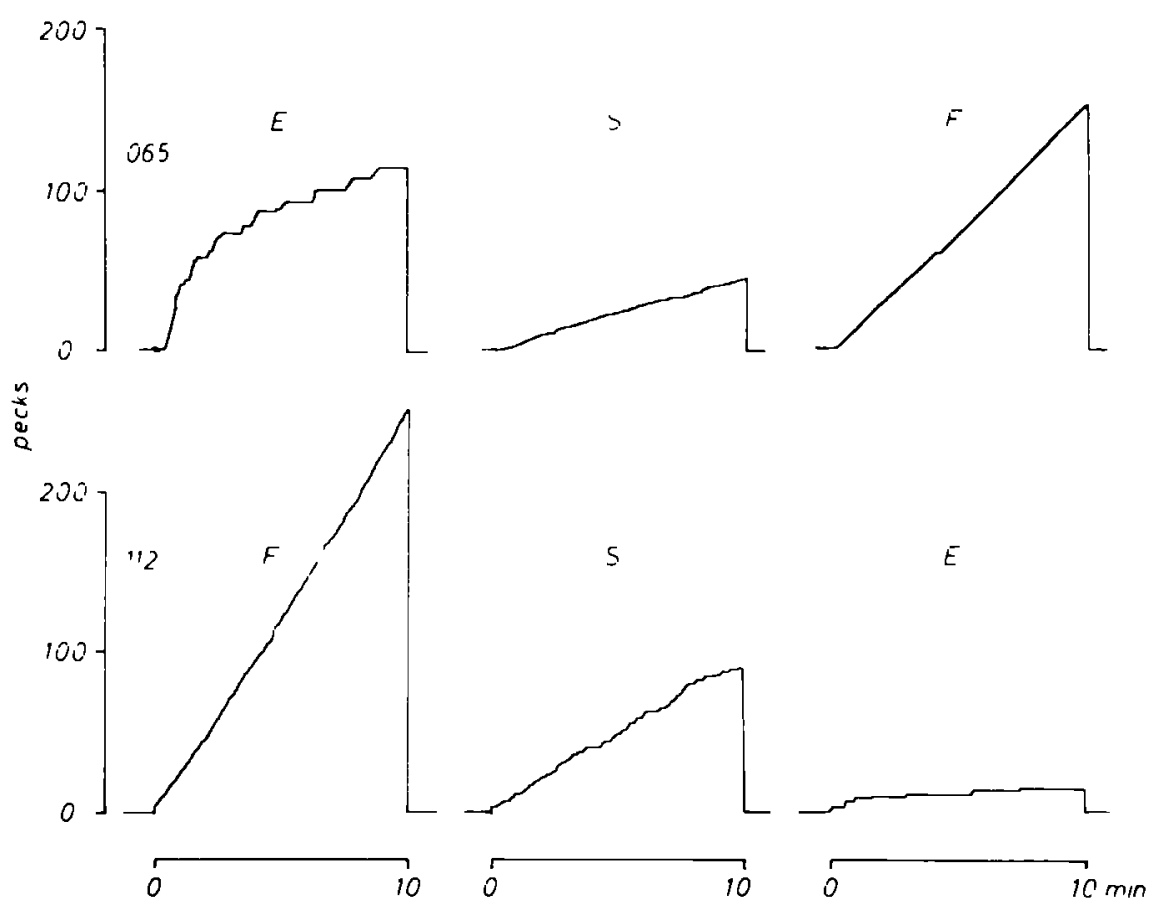

Fig 1 Sample cumulative records of two sessions (sites 065 and 112) from the identification experıment described in the text $E=$ extinction, $S=$ stımulus reward, $F=$ food reward In the session shown for electrode 065 the total number of responses in the $\mathbf{S}$ condition is less than the $\mathrm{E}$ condition, but the shape of the records is clearly different 
levels ranging between 0 and $200 \mu \mathrm{A}$ were tested in twenty-tive 15-min sessions in a random sequence A block of 5 sessions was given each day

The intensity of the stimulation current eliciting the highest rate of response ranged between 20 and $160 \mu \mathrm{A}$ for the various sites These best" currents are comparable with those reported in several self-stimulation studies on bucls (Goodman and Brown, 1966, Macphasl, 1967, Andrew, 1967, Davis et al . 1972 ) except that Webster and Beale (1970) and Hollard and Davison (1971) ieport current intensities that are unusually high We found that currents of $400 \mu \mathrm{A}$ invariably led to convulsions

The shape of the current-response functions varied considerably from site to site This probably relates to the widely' scattered anatomical location of ou sites (compare Hollard and Davison, 1971, and Davis et al , 1972) At the best current settings the response rates were in each case highel than at the $0 \mu \mathrm{A}$ current level ( $t$-tests, $p<001$ ) This confurmed the rewarding nature of stimulation at these sites From now onwards each electrode $w$ as st imulated with the corresponding best current intensity

We did not explore systematically the influence of the stimulus train duration but some early, mformal experimentation suggested that shorter, $04 \mathrm{~s}$ tians were more effective than longer, $1 \mathrm{~s}$ tiains This led to the adoption of the biefer stimulation tians as standard in the later experiments

\section{Hunger dependence}

Incidental observations suggested that the rewarding property of the stımulation depended on the food-deprived state of the anımal duing the preceding experiments Ten of the reinforcing sites were tested systematically in this regard The subjects had five $10-\mathrm{min}$ self-stimulation sessions while at 80 ; of normal bodyweight and then a further 5 sessions when they had regained full weight 5 days later Table I summarizes the results In the case of 9 of the

TABLE I

Mean responses in $10 \mathrm{~min}$ sessions at normal weight and at $80^{\circ}$ r body weight

\begin{tabular}{lccc}
\hline Electrode & \multicolumn{2}{c}{ Mean responses $/ 10 \mathrm{~min}$} & $\begin{array}{l}\text { Significance of } \\
\text { difference } p\end{array}$ \\
\cline { 2 - 3 } & 80 r weight & Full weight & \\
\hline 091 & 385 & 19 & -001 \\
093 & 86 & 0 & 001 \\
111 & 293 & 322 & n s \\
112 & 124 & 10 & -001 \\
121 & 114 & 3 & $<001$ \\
122 & 159 & 11 & $<001$ \\
123 & 411 & 17 & $<001$ \\
124 & 133 & 0 & $<001$ \\
126 & 208 & 10 & $<001$ \\
134 & 65 & 0 & -001 \\
\hline
\end{tabular}


10 sites tested the self-stimulation behaviour extinguished during the sessions at full weight ( $t$-tests, $p<001$ ) For the remaining site this was not so, the response rate was not affected by the weight manıpulation Fig 2 shows typical cumulative records from this expenment for both a deprivation-dependent site and the non-dependent site Five of the 9 sites were tested for their reinforcing property during five 10-min sessions after birds had been deprived of food again to $80^{\circ} \%$ of their weight after a period of between 2 and 5 weeks at full weight Without exception response was resumed in the absence of any priming or retraining with food reinforcement, and maintained throughout the sessions

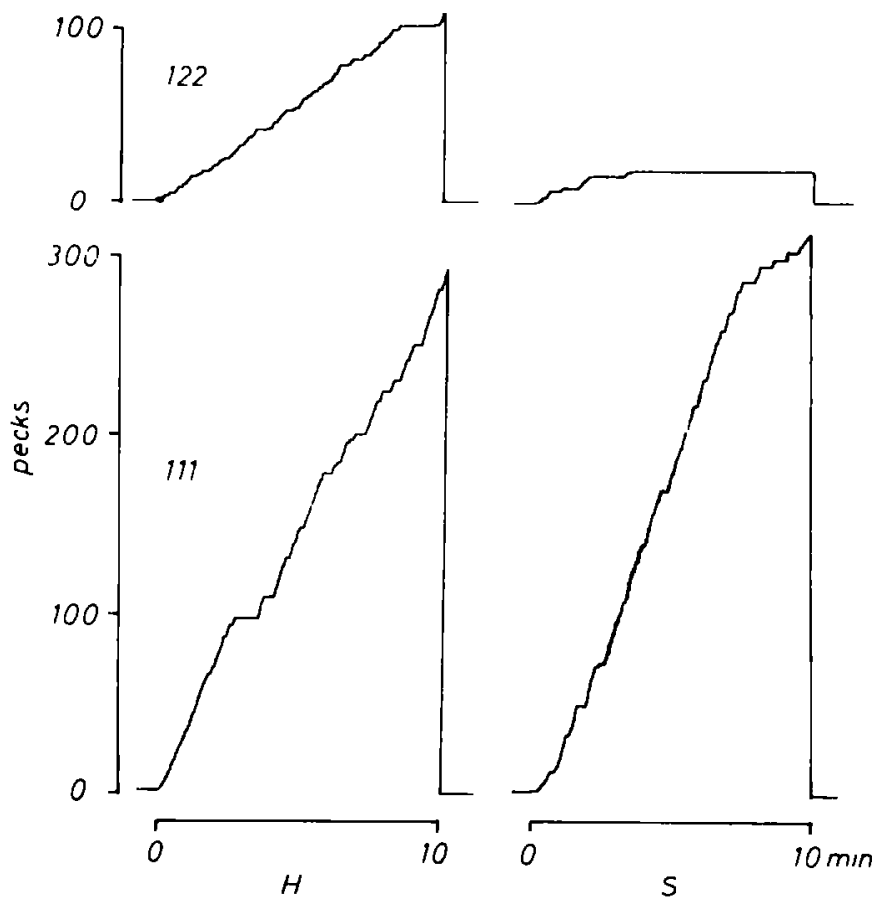

Fig 2 The effect of food deprivation on the self-stımulation rates with two electrodes in pigeons In the hungry condition $(\mathrm{H})$ the animals were at $80 \%$ of their normal weight, and in the satiated condition (S) at their normal weight and fully fed

For 3 sites several 10-min self-stimulation sessions were intercalated into the subjects' welght recovery phase, and then again as they were deprived to $80 \%$ weight for a second time The session response rates in each case correlated negatively with the current body weight ( $r$ values between -053 and -079 , $p$ between $<005$ and $<001$ ) Fig 3 illustrates this dependence for two sites, the third site produced a comparable function

The preceding result suggested that the brain stimulation of the deprivationdependent sites might have an effect similar to food reward through activation of central satiation mechanisms If this were so one might expect response saturation effects to become apparent in longer self-stımulation sessions Eight 


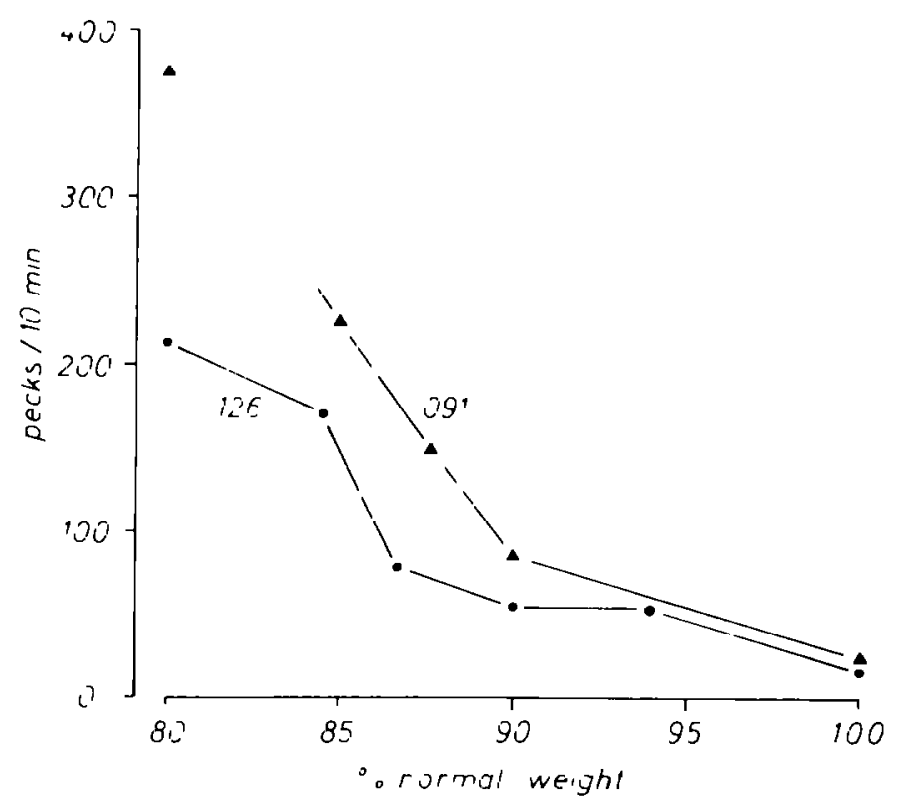

Fig 3 Food deprivation-response rate tunctions tor two self-stimulation sites in pigeon Each point is an average for two or three data points that were close logether on the weight scale, plotted at their mean weight Spearman correlation coetficients based on the original data are significant at $p<005(091)$ and $p-001(126)$

of the deprivation-dependent sites were tested in several sessions of at least 1 hour's duration Between 700 and 4750 key pecks per hour were emitted depending on the site being stimulated Each electrode produced cumulative records with a characteristic stepped pattern of its own Typical examples are shown in Fig $\&$ The pauses in response that occurred with some sites (site 134 for example) could perhaps sepresent the result of a short-term satiation process but the fine response pattern characterizing other sites cannot be confidently interpieted in this way (compare Olds, 1958b)

\section{Overt behaviour}

In the same vein it was conceivable that the hunger-dependent self-stımulation sites might yield overt feeding behaviour upon experimenter-controlled, noncontingent stimulation (compare Goldstem et al , 1970) The behaviour elicited by such stimulation was recorded for 58 electrodes, including 14 of the rewarding sites, during at least 30 stimulation trials each A variety of current levels ( 0 to $150 \mu \mathrm{A}$ ) and train durations ( 05 to $60 \mathrm{~s})$ was used including, where relevant, those that were rewarding Each stımulation settıng was tried in not less than 2 trials

Only one of the rewarding sites yielded food-related behaviour, a cliffuse facilitation of feeding, similar to that described by Harwood and Vowles (1966) 


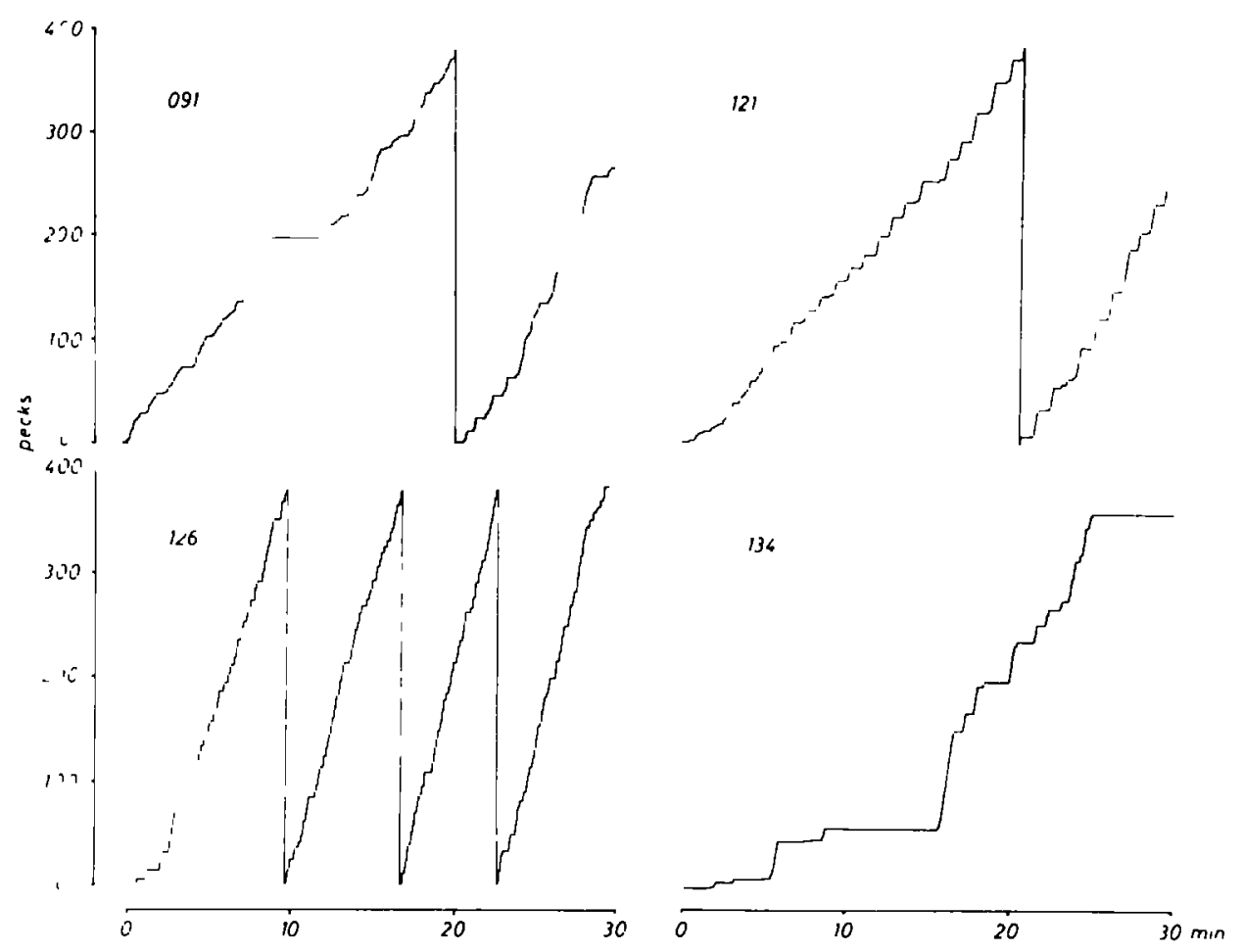

Fig 4 Sample of self-stımulation cumulative records obtaıned durıng extended sessions with four different electrodes in pigeons Note the varying stepped patterns of the records

as following stimulation of various forebrain sites in the dove (Streptopelia risoria) It must be remarked, however, that clear-cut stımulus-bound eatıng is very rarely obtained in birds (Wright, 1975) and furthermore that, differing from the self-stımulation experiments, the animals were not now deprived of food On the other hand, the association of self-stimulation and elicited feeding that unquestionably exists in rats represents somewhat of a paradox On general grounds reinforcement would be expected to be associated with the cessation rather than with the initiation of food intake (but see Hoebel, 1969)

More generally, with perhaps one exception, we could find no indication whatsoever of any consistent correspondence between the overt behaviour elicited by a given electrode and its rewarding or non-rewarding property Thus, for example, of 12 electrodes that yielded an attentive posture followed by turning during free stimulation, only 3 maintaned self-stimulation Similarly one bird bore 5 electrodes that reliably elicited nearly identical bow-cooing behaviour during non-contingent stimulation, but only 2 of them yielded selfstımulation

The possible exception to this lack of correlation between overt behaviour and stimulation is perhaps the inactivity and drowsiness sometimes associated 
with grooming, that we noticed during and after non-contingent, long duration stimulation ( 60 strains) of 3 out of 4 positively reinforcing medial neostriatum intermedium sites It is interesting to note that one of the areas mentioned in connection with a similar syndrome elicited in gulls by electrical brain stimulation was also the neostratıum intermedium (Delius, 1967, 1970, and unpublished) and that Goodman (1974) also reports a few sites in this area y'ielding drowsiness and sleep This association between self-stımulation and dearousal needs to be confurmed before it is considered any further

\section{Localization}

To determine the location of the electrode tips the pigeons were sacrificed and theil heads were perfused through the carotids and fixed in formalin After withdrawal of the electrodes the brain was removed from the skull and sectioned $(25 \mu)$ transversely in the same plane as the electrode tracks on a freezing microtome The sectıons were stained with cresyl violet Electiode tips were identıfied with the aid of a microscope and transferred onto stereotactic atlas (Karten and Hodos, 1967) drawings These are illustrated in Fig 5 The figure also includes the reinforcing sites that have been localized in pigeons by other authors, who are listed in the legend

In birds the quinto-frontal and the fronto-archistriatal tracts have been shown to be essential for the regulation of food intake (Zeigler, 1974) Five of the self-stimulation positive sites are in the immediate vicinity of these structures but only two were shown to be food-deprivation dependent the fifth is the one that was shown to be independent of the hunger state Since the location of the remaining 7 motivation-dependent sites cannot be related with confidence to structures definitely controlling feeding, the issue remains undecided The fact that there is still uncertainty regarding the extension of the neural substrates of feeding in burds (Wright, 1975, Delıus, 1971) adds to the difficulty

A cluster of reinforcing sites in the lateral anterior hypothalamus have been reported by Davis et al (1972), and Andrew (1969) refers to active sites in the posterior hypothalamus of the chick Hypothalamic self-stimulation sites in mammals have often been related to the presence there of substrates regulating hunger and thirst (Hoebel and Teitelbaum, 1962) In burds, however, the involvement of the hypothalamus in food intake regulation is not so definite (Wright, 1975, see also Grossman, 1975) In any case, none of the sites in question appears to have been hunger-dependent

A group of positive sites is noticeable in the medial neostriatum intermedium This confirms the findings of other authors (Macphal, 1967, Webster and Beale, 1970, and possibly Andrew, 1969, he only mentions the neostriatum) We note that Harwood and Vowles (1966) obtained a diffuse faculitation of feedıng (and preening) with electrical stimulation of this area in doves

Another structure that emerges as supporting self-stimulation is the paleostriatum (similarly mentioned by Harwood and Vowles) and the lateral forebrain bundle that contains, among others, fibres efferent and afferent to the 


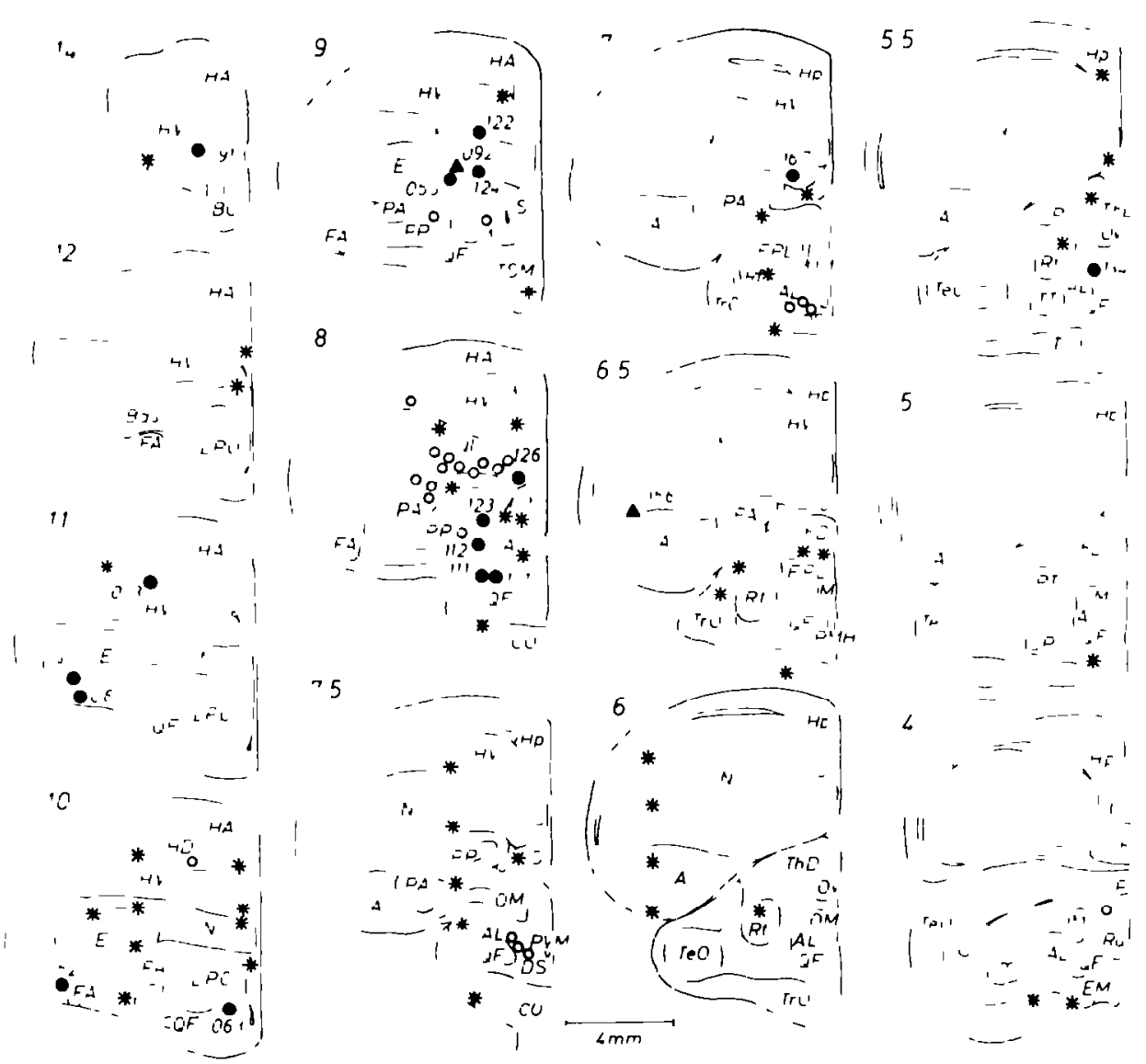

Fig 5 The location of the rewarding (dots), aversıve (triangles) and neutral (asterisks) sites found in the brain of the pigeon For one rewarding site (probably medial neostriatum intermedium) and a neutral site histology is lacking Rewarding sites from Goodman and Brown (1966), Macphail (1967), Webster and Beale (1970) and Davis et al (1972) have been entered as curcles For convenience all points have been transfered to one side of the brain $A=$ archistriatum, $A L=$ ansa lenticularıs, $B a s=$ nucleus basalıs, $B O=$ bulbus olfactorıus, $\mathrm{CA}=$ commissura anterior, $\mathrm{Cb}=$ cerebellum, $\mathrm{CO}=$ chiasma opticum, $\mathrm{DS}=$ decussat 10 supraoptıca, $\mathbf{E}=$ ectostriatum, $\mathrm{EM}=$ nucleus ectomamılarıs, $\mathrm{HA}=$ hyperstriatum accessorıum, $\mathrm{HD}=$ hyperstrıtum dorsalıs, $\mathrm{Hp}=$ hıppocampus, $\mathrm{HV}=$ hyperstriat um ventrale, Imc $=$ nucleus isthmı magnocellularis, FA = tractus fronto-archistriatıcus, FPL = fasciculus prosencephalı lateralıs, LPO = lobus paraolfactorıus, $\mathbf{N}=$ neostrıat um, $\mathbf{N C}=$ neostriatum caudale, $\mathrm{NI}=$ neostrıtum intermedıum, $\mathrm{OM}=$ tractus occıpıto-mesencephalıcus, $\mathrm{Ov}=$ nucleus ovoidalıs, $\mathrm{PA}=$ paleostriatum angmentatum, $\mathrm{PMH}=$ nucleus posteromedialıs hypothalamı, PP = paleostriatum primitıvum, PT = nucleus pretectalıs, $\mathbf{P V M}=$ nucleus posteroventralıs medıalıs, $\mathbf{Q F}=$ tractus quıntofrontalıs, $R t=$ nucleus rotund us, $R u=n u c l e u s$ ruber, $\mathrm{S}=$ septum, $\mathrm{SP}=$ nucleus subpretectalıs, $\mathrm{SPC}=$ nucleus superficıalıs parvocellularıs, $\mathrm{TeO}=$ tectum opticum, ThD = thalamus dorsalis, TrO = tractus opticus, TSM = tractus septomesencephalıcus, $\mathrm{TT}=$ tractus tecto-thalamıcus 
paleostratum (Macphall, 1967, Goodman and Brown, 1966, our data)

Andrew $(1967,1969)$ reports sites in the tractus septomesencephalicus and the neighboumng septum of the chick as positively reinforcing Goodman and Brown (1966), Macphall (1967), Davis et al (1972) and our data, however, indicate that stimulation of the medial forebrain bundle and the septal area in pigeons is not reinforcing, though in mammals these areas support selfstimulation

Hollard and Davison (1971) and again Davis et al (1972) mention selfstimulation sites in the ectostriatum Macphail's (1967) and our few sites in this structure did not lead to self-stimulation The issue is of some interest because the ectostriatum is known to be a major visual projection area (Karten, 1969) Andrew (1969) funally mentions hippocampal positively reinforcing sites in chicks but a few sites of ours do not confirm this for the pigeon

\section{DISCUSSION}

The issue of motıvational dependency requires fur ther comment While increments in rates of self-stımulation with food deprivation do occur in rats (Olds, 1958a, Blundell and Herberg, 1968, Goldstem et al , 1970, Gallistel and Beagley, 1971, Drewett and Herberg, 1975) the dependence is not as absolute as that observed by us in pigeons where self-stimulation ceased completely' when the subjects were satiated in the case of 9 sites out of 10 The situation was similar in one of two self-stimulation sites studied by Goodman and Brown (1966), and Macphall (1966) also makes reference to a deprivation dependence concerning some of the sites he dealt with

W'e must consider the possibulity that the procedure of initially shaping key'-pecking with food reward and then testing the rewarding quality of electrical stimulation by its capacity to maintain responding might have somehow been instrumental in bringing about the deprivation dependence One mechanism by which this could have occurred, namely that the electrical stimulation acquired secondary reinforcement properties through association with food reward, can be excluded since at no time cluring the experiment was there any short-term contingency between the two events Furthermore, apart from the initial test, the animals were exclusively reinforced with brain stimulation Several of the sites served successfully in further experiments not reported here, for example, an experiment involving responding under intermittent brain stimulation reward, and another involving visual pattern discrimination learning with the same reward, without ever receiving food other than in the home cage Any tenuous associations that might have arisen in the initial tests can surely be expected to have extınguished (see also Macphal, 1968) Nonetheless, it must be examıned empincally whether brain sites can be found whose stimulation does not lead to shapıng of key-peckıng when the pigeons are satiated but does when they are deprived, without the operant response being initially shaped with a food reward Additionally, there is the question of the motivation specificity A preliminary experiment with one of our sites indicated that water deprivation cannot replace the food depr- 
vation but this needs to be examined more thoroughly (see also Macphal, 1966) If the above finding were confirmed, could one then find sites whose reinforcing property is specifically thirst dependent? (Compare Gallistel and Beagley, 1971 )

At this stage the simplest hypothesis seems to be that stimulation at the deprivation-dependent sites generates satiety signals partially equivalent to those produced by rewarding food ingestion The fact that response saturation did not occur reliably in our extended sessions could be due to the circumstance that whle repeated food consumption leads to satiation signals integrating over time, electrical stımulation only generates transitory, non-cumulative signals If this difference can be overcome with longer stimulation trains it would be possible to test whether the stimulation would inhibit food consumption, as satiation signals should A preliminary experiment done with one of the hunger-dependent sites supports this equivalence hypothesis It indicated that free access to food for 5 minutes, not leading to an appreciable weight gain of the animal (short-term satiation) was effective in suppressing selfstimulation for the following 10 to 15 minutes (compare Blundell and Herberg, 1968, Hoebel, 1969)

While we only found the stimulation of one site to be rewarding independently of food deprivation, other authors (Macphal, 1966, Goodman and Brown, 1966, Andrew, 1967, 1969, Webster and Beale, 1970, Davis et al , 1972) have identified a number of sites that do not depend on the induction of an identifiable motivational state The reinforcing qualities of electrical brain stimulation do not differ in this respect from normal rewarding events It is now sufficiently plain that many natural reinforcers are capable of supporting instrumental learning in the absence of any specific motivational manipulations whereas others are only effective when gated by specified drive states

\section{ACKNOWLEDGEMENTS}

We wish to thank D Harper, D Barton, M Rolling, J Owen, Miss C Chaudour, Miss B Craig and Dr D Parker for assistance of various kınds While carryıng out this research R J W held a Science Research Council postdoctoral fellowship The investigation was supported by a Science Research Councll grant to J D D

\section{REFERENCES}

Andrew R J, 1967 Intracranial self-stimulation in the chich Nature, Lond, $213847-$ 848

Andrew, R J , 1969 Intracranıal self stımulation in the chick and the causation of emotional behaviour Ann N Y Acad Scı, 159 625-639

Blundell, J E and Herberg, L J, 1968 Relatıve effects of nutritıonal deficit and deprivatıon period on rates of electrical self-stımulation of the lateral hypothalamus Nature, Lond, $219627-628$ 
Davis, A H , Davison, M C and Webster, D MI, 1972 Intracranial reinforcement in the pigeon an analysis using concurrent schedules Physiol Behav, 9 385-390

Delıus, J D , 1966 Some technıques for the electrıcal brain stımulatıon of small un restrained anımals Mled Bıol Eng, 4 393-397

Delius, J D , 1967 Displacement activities and arousal Nature, Lond, 214 1259-1260

Delıus, J D , 1970 Irrelevant behaviour, information processing and arousal homeostasis Psychol Forsch , 33 165-188

Delıus, J D , 1971 Foragıng behav'our p tterns of herrıng gulls elicited by electrical forebrain stımulation Experientia, 27 1287-1289

Drewett, R F and Herberg, L J , 1975 Hypothalamıc self-stımulation in the female rat effects of oestrus and food cleprivation Physiol Behav , 14 285-289

Gallistel, C R, 1973 Self-stimulation the neurophysiology of reward and motisation In J A Deutsch (Edıtor), Physıological Basıs of Memory Academic Press, New York, pp $175-267$

Gallıstel, C R and Beagley, G, 1971. Specificity of brain stımulation reward in the rat J Comp Physiol Psy chol, 76 199-205

Goldsteın, R S , Hıll, T E and Templer, D I , 1970 Effects of tood deprivation on hy po thalamic self-st ımulation in stımulus bound eaters and non-eaters Phy'sıl Behai, 5 $915-918$

Goodman, I J , 1974 The study of sleep in birds In I J Goodman (Editor), Birds Brain and Behavior Academic Press, New York, pp 133-164

Goodman, I J and Brown, J L , 1966 Stımulation of positıvely and negatively remiorcing sites in the avian brain Life Scı, 5 693-704

Grossman, S P , 1975 Role of the hy pothalamus in the regulation of food and water intake Psy'chol Bull, 82 200-22-4

Harwood, D and Vowles, D M , 1966 Forebrain stımulation and feedıng behaviour in the ring dove J Comp Physiol Psychol, 62 388-396

Hoebel, B G , 1969 Feedıng and self-stımulation 4nn N Y Acad Scı, 157 758-778

Hoebel, B G and Teitelbaum, P , $1962 \mathrm{Hy}$ pothalamıc control of feeding and selt st imulation Science, 135 375-377

Hollard, V and Davison, M C , 1971 Preterence for qualıtatıvely different reintoicers J Exp Anal Behav, 16 375-380

Karten, H J , 1969 The organization of the avian telencephalon and some speculations on the phylogeny of the amniote telencephalon Ann N Y Acad Sci, 159 625-639

Karten, $H$ J and Hodos, W A , 1967 A Stereotaxic Atlas of the Brain of the Pigeon Johns Hophins, Baltımore, 193 pp

Lenzer, I, 1972 Differences between behaviour reintorced by electrical stımulation of the brain and conventionally reinforced behaviour Psychol Bull, 78 103-118

Macphail, E M, 1966 Self-stımulation the problem of primıng Psychon Scı, 5 7-8

Macphail, E M , 1967 Positive and negative reinforcement from intracranıal stımulation in pigeons Nature, Lond, 213 947-948

Macphall, E M , 1968 Self-stımulation in pigeon tests of two alternative explanations Psy chon Scı, 11 3-4

Olds, J , 1958a Effects of hunger and male sex hormone on self-stimulation ot the brain J Comp Phy'siol Psy'chol, 58 320-324

Olds, J , 1958b Satiation effects in self-stımulation of the brain J Comp Phy'sıol Psychol, $58 \quad 675-678$

Reynolds, R W , 1958 The relatıonship between stımulation voltage and rate of hı pothalamıc self-stımulation in the rat $\mathrm{J}$ Comp Physiol Psychol, 58 193-198

Rolls, E T, 1975 The Brain and Reward Pergamon Press, Oxford, $115 \mathrm{pp}$

Webster, D M and Beale, I L , 1970 Intracranial self-stımulation in the pigeon the effect of current intensity Psychon Scı, 20 15-17

Wright, P , 1975 The neural substrate of feeding behaviour in birds In P Wright, P G 
Caryl and D M Vowles (Editors), Neural and Endocrine Aspects of Behavıour in Birds Elsevier, Amsterdam, pp 319-349

Zeıgler, H P , 1974 Feeding behaviour in the pigeon a neuro-behavioral analysis In

I J Goodman (Edıtor), Birds Brain and Behaviour Academic Press, New York, pp 103-132 